\title{
Europe Against the Left? On Legal Limits to
}

\section{Progressive Politics}

Bojan Bugaric

LEQS Paper No. 61/2013

May 2013

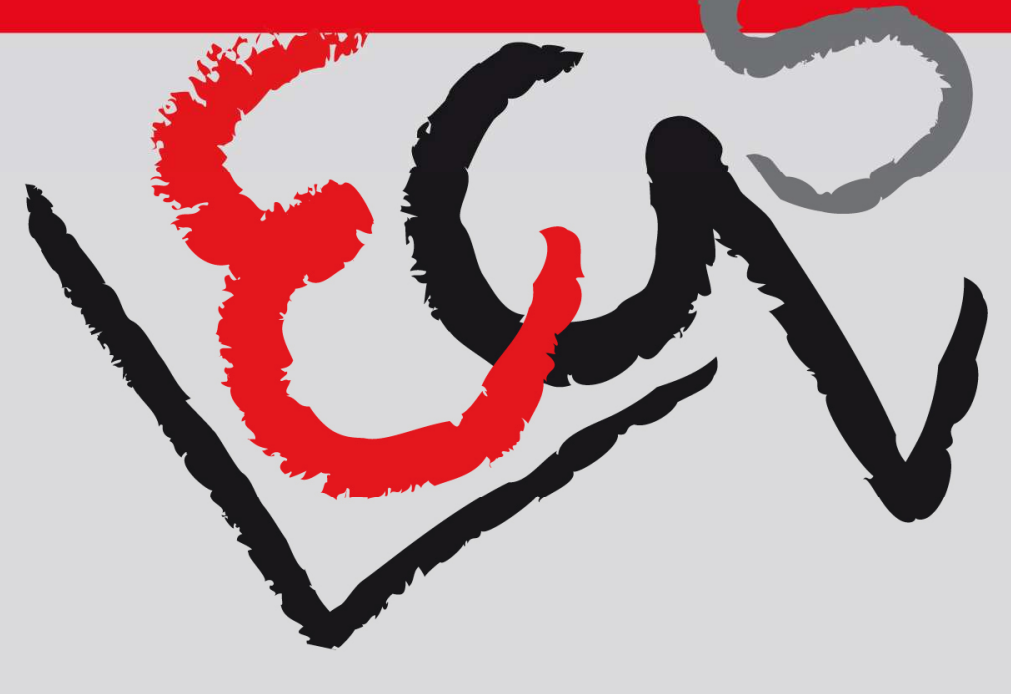




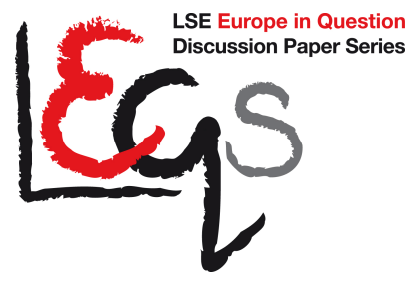

\author{
Editorial Board \\ Dr Mareike Kleine \\ Dr Vassilis Monastiriotis \\ Dr Jonathan White \\ Dr Katjana Gattermann
}

All views expressed in this paper are those of the author and do not necessarily represent the views of the editors or the LSE.

(C) Bojan Bugaric

Egs 


\title{
Europe Against the Left? On Legal Limits to
}

\section{Progressive Politics}

\author{
Bojan Bugaric*
}

\begin{abstract}
The EU »economic constitution « systematically biases EU policy making in a neo-liberal direction. Historically speaking, this was not the intent of the EU founding fathers. The original constitutional settlement of embedded liberalism was significantly redefined in the next major revisions of the Rome Treaty. The neo-liberal foundations of the single market and the EMU have imposed real and significant institutional constraints for progressive policy making. However, the role of the European Left was crucial in this alteration of the EU constitutional order. Despite the strong neoliberal consensus among the key political actors of that time, such a change would have not be possible without the Left' retreat towards »centreleftism «, particularly in France. Furthermore, while constraints of the EU economic constitution are significant, we should avoid the "naturalization « of the EU project. The European Left, while in power, failed to leave its distinct imprint on the EU economic constitution. The Left policy agenda remained firmly embedded in the logic of the nation state. The euro crisis pushed these developments even further and, for the first time in the EU history, explicitly challenged the constitutional balance of the EU legal order. The new Austerity Union, a project in the making, profoundly altered this constitutional balance.
\end{abstract}

Keywords: Constitutional law, EU economic constitution, European left, neo-liberalism, Austerity Union

* Faculty of Law, University of Ljubljana

Professor of Law, Faculty of Law, University of Ljubljana, Poljanski nasip 2, 1000 Ljubljana, Slovenia tel: 386142031 76, fax: 38614203115 Slovenia

Email: Bojan.bugaric@pf.uni-lj.si 


\section{Table of Contents}

Abstract

$\begin{array}{ll}\text { I. Introduction } & 1\end{array}$

II. The European Rescue of the Nation State

III. From embedded liberalism to embedded neoliberalism?

IV. Divided EU Left and European Integration

V. Toward European Austerity Union: EU Constitution after the Euro crisis

VI. Conclusion: Constitutional limits to Progressive Politics? 29

\section{Acknowledgements}

I have benefited from commentary and advice on earlier drafts from Daniel Brinks, Christian Joerges, Andrew Johnston, Floris de Witte, Jacques Ziller and other participants of the conference "Doing Law Beyond the State", Research Methodologies in Comparative, EU and Public and Private International Law, School of Law, University of Sheffield, 18-19 January 2013. 


\section{Europe Against the Left? On Legal Limits to Progressive Politics}

\section{Introduction}

At the moment, only seven out of twenty seven member states of the European Union (EU) are governed by left parties or left dominated coalitions. ${ }^{1}$ On the EU level, the Left fares even worse. The last European elections in 2009 brought the Left the worst defeat since the first elections to the European parliament in 1979. The European Council and the European Parliament, two legislative bodies of the European Union (EU), are firmly in the hands of centre-right political parties, and equally is the European Commission, the executive body of the EU.

Paradoxically, the European Left ${ }^{2}$ is on the wane precisely when the 'objective conditions' of the world economy seem to work for the Left. When the worst economic crisis of capitalism since the Great Depression hit Europe, many expected a strong comeback of the European Left. The economic crisis, ultimately the end result of neoliberal deregulatory ideology and policies, was rightly perceived as a great window of opportunity for the Left, which could not have been blamed for the disastrous consequences of neoliberal economic and political policies of the centre-right parties in power. Not only economic conditions but also favourable modernizing demographic trends are shifting

\footnotetext{
${ }^{1}$ The Guardian, Left, right, left: how political shifts have altered the map of Europe, available at: http://www.guardian.co.uk/world/interactive/2011/jul/28/europe-politics-interactive-mapleft-right?INTCMP=SRCH

2 By the Left I understand political parties which, comparatively speaking, on a left-right scale, more strongly support equality as a precondition for social change. Here I follow Noel and Therien's definition of the left-right distinction. See A.Noel, J.P. Therien, Left and Right in Global Politics (Cambridge University Press, 2009), at 6-10. I would like to thank an anonymous reviewer for this suggestion. On the other hand, I do not try to distinguish between different »versions « of the Left.
} 
the political terrain in favour of the Left. The rise of a progressive younger generation, the increase in immigrant population, the growth of the professional class and the increasing social weight of single and alternative households and growing religious diversity and secularism, combined with the Left traditional base among the working class, makes them 'the natural beneficiaries of modernity'.3

Yet, despite these favourable socioeconomic conditions, the European Left has failed to persuade the voters. The European Left not only suffered some of the worst electoral defeats in the recent history, it also does not seem to possess a convincing political program offering a credible alternative to the centrist pragmatism of European centre-right parties. As the EU is facing its most serious institutional and political crisis since its inception, the European Left is notably absent from public debate on how to solve the Eurozone debt crisis. Politically weakened, the European Left is on defensive and instead of offering solutions, it reacts to the new politics of fiscal austerity and balanced budget fundamentalism of the centre-right parties.

Since the start of the euro-zone crisis in 2010, governments across the continent have responded by imposing fiscal austerity. The new politics of fiscal austerity do not mean only double digit cuts of governments' spending but also the elevation of the austerity paradigm of the German Chancellor Angela Merkel to the status of 'unbreakable law'. The new Fiscal compact, an intergovernmental treaty signed by all EU members but the UK and the Czech Republic, basically outlaws Keynesianism and its counter-cyclical economic policies and constitutionalizes austerity and balanced budgets as new fundamental principles of the EU constitutional order. As Newman sarcastically argues, such developments should make Tea Party loyalists in

\footnotetext{
3 M.Browne, J.Halpin, R.Teixeira, 'The European Paradox', Center for American Progress,
} September 2009, 1. 
the United States green with envy. ${ }^{4}$ He elaborates that the politics of fiscal austerity will transform Europe's political economy in the long term, strengthening the neoliberal ideas of limited government and loosely regulated markets while simultaneously precluding any alternative socialdemocratic framework.

What these new developments offer is a new perspective on the political economy of the EU integration. If only four decades ago it was still possible to ask whether the Left should be against Europe ${ }^{5}$, today the question has to be reframed: is Europe, its politico-legal framework, working against the Left? Is the European Left confronted with a distinct constitutional order, which, because of its pro-market neoliberal bias, radically limits the ability of the Left to pursue its political programme? As Perry Anderson reminds us, it was Friedrich von Hayek who basically foresaw a development of a constitutional structure of an inter-state federation which would structurally limit the ability of electorates to enact dirigiste and redistributive policies. ${ }^{6}$ The major obstacle that such interstate federation would erect against pursuing redistributive polices is the lack of international solidarity required to sustain such policies. ${ }^{7}$ When compared with the most recent political developments in the EU, Hayek's words from 1939 look like a prophecy.

During the last two decades the EU evolved into a new kind of political order making it difficult to pursue a genuine Left political agenda. Namely, the EU entered a new phase of integration which has radically transformed the EU capacity to combine liberalism of common economic market with redistributive social policies either on the national or the EU level. As Höpner

\footnotetext{
${ }^{4}$ A.Newman, 'Austerity and the End of the European Model: How Neoliberals Captured the Continent', May 1, 2012, available at http://www.foreignaffairs.com/articles/137611/abrahamnewman/austerity-and-the-end-of-the-european-model

5 T.Nairn, 'The Left Against Europe?', (1972) I/75 New Left Review 5-120.

6 P.Anderson, The New Old World (Verso, 2010), at 64-65.

${ }^{7}$ F.A.Hayek, 'The Economic Conditions of Interstate Federalism', in F.A. Hayek, Individualism and Economic Order ( Routledge \&Kegan Paul Ltd., 1952), at 266.
} 
and Schäfer argue, the EU has come closer to Hayeks' neoliberal vision of inter-state federation than to the socially embedded liberal economic regime as envisaged by its founding fathers. ${ }^{8}$ Their vision, codified in the first EU Treaty in 1957, was somehow different. As most convincingly shown by historian Milward, the original constitutional settlement represented a compromise between international free trade and domestic state interventionism, a European version of what has later to become known as 'embedded liberalism'. ${ }^{9}$

Nowadays, important economists, political scientists and lawyers write about a 'political trilemma' of the EU making it difficult ${ }^{10}$ if not structurally impossible $\mathrm{e}^{11}$ to combine common economic market and redistributive social policies on the EU level. In its most extreme form, the argument about the neoliberal bias of European constitutional order postulates that it is structurally impossible to develop an EU version of social market economy. Fritz Scharpf, one of leading scholars of European integration, argues that

the socio-economic asymmetry of European law is caused by structural conditions whose effect does not depend on the ideological orientations of members of the Court or the Commission. For this same reason, it can hardly be corrected through changes in the party-political composition of the Council or through elections to the European Parliament. ${ }^{12}$

According to this theory, the law, in the form of the European constitution, determines the politics of the European Union. The European Constitution, a

\footnotetext{
8 M.Höpner, A.Schäfer, 'Embeddedness and Regional Integration: Waiting for Polanyi in a Hayekian Setting', (2012) 66 International Organization 429.

9 J.G. Ruggie, 'International Regimes, transactions, and change: embedded liberalism in the postwar economic order', (1982) 36 International Organization 392.

10 D.Rodrik, The Globalization Paradox: Democracy and the Future of the World Economy ( W.W. Norton \&Company, 2011), at 220; K.H. O’Rourke, 'A Tale of Two Trilemmas', March 2011, Department of Economics and IIIS, Trinity College Dublin, 3.

11 F.W.Scharpf, 'The asymmetry of European integration, or why the EU cannot be a "social market economy"', (2010) 8 Socio-Economic Review 243.

12 ibid, 243.
} 
legal superstructure, has, so to speak, a life of its own and crucially determines the base, the relations of production. In other words, the European Left is confronted with a distinct EU constitutional order, which, because of its neoliberal bias, radically limits the importance of the Left's political agenda.

While in broad terms sympathetic to this powerful theory, this article offers an alternative explanation for the fundamental asymmetry between the neoliberal and social agenda in the EU legal order. The crucial reason for the absence of more developed 'social Europe' is not only the structure of the EU constitutional order as such but also the reluctance and inability of the Left to 'Europeanize' its social agenda. ${ }^{13}$ The Left thinking and policy proposals concerning 'social Europe' have remained firmly embedded in the logic of the nation state. The Left urgently needs a new post-national approach to 'social Europe'.

In the first four sections of the article I chronicle four different episodes of the institutional settlement between the market and the social in the EU legal order. In the last section I discuss policy alternatives to the current austerity approach to the euro crisis.

\section{The European Rescue of the Nation State}

The relationship between the European Left and European integration was always a complex one. The European Economic Community (EEC), from its inception, was not a Left project. George Ross argues that the real movers of European integration were Centre-Right Christian Democrats, who were

13 G.Moschonas, 'When institutions matter: the EU and the identity of social democracy', (2009) 17/2 Renewal 13. 
haunted by World War II. ${ }^{14}$ The European Left of that era was more focused on national systems of economic and political development and was not very enthusiastic about European integration. However, with the exception of the two largest Communist parties (PCF and PCI), other socialist or socialdemocratic parties in principle did not oppose the project of European integration. ${ }^{15}$ As mostly opposition parties, they did not leave their imprint on the construction of an integrated Europe. Their primary concern was to keep the welfare state and its redistributive policies firmly within the jurisdiction of the nation state.

A constitutional compromise reached during the negotiations leading to the Treaties of Rome was to decouple economic integration from social protection issues. $^{16}$ Whereas the first was constitutionalised in the 'economic constitution', 'the social' was put on a separate track and remained mostly national. ${ }^{17}$ This fact is often overlooked by those accounts which argue that the Treaties of Rome represented an overwhelming victory of neo-liberalism over the French attempt to institutionalize a more regulated Europe. ${ }^{18}$ In reality, both Christian Democrats and Social Democrats were, although for different reasons, strong supporters of the welfare state. Hence, both camps have their own reasons not to transfer social policy to the European level. ${ }^{19}$

14 G.Ross, 'European Center-Lefts and the Mazes of European Integration', in J. Cronin, G.Ross, J.Shoch (eds), What's Left of the Left: Democrats and Social Democrats in Challenging Times, (Duke University Press, 2011), at 321.

15 D.Sassoon, One Hundred Years of Socialism: The West European Left in the Twentieth Century (The New Press, 1996), at 229.

16 F.W.Scharpf, 'The European Social Model: Coping with the Challenges of Diversity', (2002) 40 Journal of Common Market Studies 646.

17 C.Joerges, 'Rechstaat and Social Europe: How a Classical Tension Resurfaces in the European Integration Process', (2010) 9 Comparative Sociology 70; A.S. Milward, The European Rescue of the Nation State, $2^{\text {nd }}$ edition (Routledge, 2000), at 216.

18 M.A.Pollack, 2000. 'A Blairite Treaty: Neo-Liberalism and Regulated Capitalism in the Treaty of Amsterdam', in K.Neunreither, A.Wiener (eds), European Integration After Amsterdam: Institutional Dynamics and Prospects for Democracy (Oxford University Press, 2000), at 271-272. 19 P.Manow, A.Schäfer, H. Zorn, 'European Social Policy and Europe's Party-Political Center of Gravity, 1957-2003', MPlfG Discussion Paper, 2004/6, 19; A.J.Menendez, A, 'The Existential Crisis of the European Union', (2013) German Law Journal, Forthcoming. 
The Treaties of Rome thus represented a compromise between two different visions of European integration. On the one hand we find German ordoliberals, strongly represented in the German delegation, strongly favouring economic freedoms as the key instrument of integration, while on the other hand both Christian Democrats and Social Democrats embraced the vision of regulated capitalism at home combined with open trade on the European level, or the 'Smith abroad, Keynes at home' compromise. Such a constitutional compromise can also be explained by the fact the Treaties of Rome were signed in a particular socioeconomic context, i.e., during the golden age of the Keynesian welfare state. As a consequence, the constitutional settlement codified in the Treaties of Rome can be best described as a model of embedded liberalism, which tried to accommodate open markets aimed at securing economic growth with domestic political intervention protecting 'societies from capitalism's destructive and destabilizing tendencies'. ${ }^{20}$ The first European constitution therefore consisted of rules written in the Treaties themselves and implicit rules excluding majority of social issues from the ambit of the EEC jurisdiction. ${ }^{21}$

As the EEC during the first two decades did not evolve into more than a customs union, the national systems of social protection could expand rapidly. As a consequence, the European »economic constitution« could coexist easily with nationally based systems of social protection and development. While member states could gain from the advantages of the »common market«, at the same time, they were able to continue with the postwar state led development of national welfare states. As argued by Milward, the aim of European integration was to 'rescue the nation state':

\footnotetext{
${ }^{20}$ S.Berman, 'European Disintegration? Warnings from History', (2012) 23 Journal of Democracy 7.

21 S.Giubboni, Social Rights and Market Freedom in the European Constitution (Cambridge University Press, 2006), at 16.
} 
The problem genuinely was how to construct a commercial framework which would not endanger the levels of social welfare which had been reached...The Treaties of Rome had to be also an external buttress to the welfare state. ${ }^{22}$

As long as this was possible, the Left did not have strong incentives to challenge the project of European integration. Rather, the Left 'remained by and large a passive bystander, occasionally voicing criticism yet without challenging the project at its core'. ${ }^{23}$ In other words, even though the Treaties of Rome bore the strong imprint of economic liberalism, such framework was perfectly compatible, both for the Left and the Centre-Right, with nationally based welfare states.

However, the turning point came in the 1980s. After the turbulent decade of stagnation and 'eurosclerosis', European integration gained a new momentum with the adoption of the Single European Act (SEA) in 1986 and the Maastricht Treaty (TEU) in 1992. As argued by Moravcsik, both revisions of the original Treaty were the consequence of a broad political convergence among the key member states (Germany, France and Britain) towards the neoliberal goal of creating a single European market.$^{24}$ The relaunching of European integration thus coincided with a major shift in the political ideology. The golden age of the Keynesian welfare state did come to an end and gave its way to a new powerful ideology - pro-market neoliberalism.

\footnotetext{
22 Milward, n 16 supra, 216.

23 O. Cramme, 'The power of European integration: Social democracy in search for purpose', Policy Network Paper 2011, 5.

24 A. Moravcsik, The Choice for Europe: Social Purpose\& State Power from Messina to Maastricht (Cornell University Press, 1998), at 317.
} 


\section{From embedded liberalism to embedded neoliberalism?}

With both revisions of the original Rome Treaty, the European Union moved decisively into an economic and a monetary union. The SEA was followed by a massive program of EC legislation aimed at removing all non-tariff barriers to a »single market« consisting of free movement of goods, services, capital and people. By the target date of the completion of the single market, the end of 1992, 260 out of 279 measures listed in the White Paper had been adopted in the Council of Ministers, which represented 'a staggering 95 per cent success rate'. ${ }^{25}$ It goes without saying that such a result would not be possible without a major institutional innovation adopted in the SEA which introduced qualified majority voting for single-market measures. However, equally important was the neoliberal consensus among Thatcher, Kohl and Mitterand on the importance of the single market promising Europe economies of scale needed to compete with rival economies of the US and Japan (Moravcsik, 1991, 42). ${ }^{26}$ As both Moravcsik and Pollack argue, the SEA was 'a quintessentially neoliberal project'.${ }^{27}$ At that time, centre-right parties enjoyed a strong majority across Europe.

However, France, one of the key member states, was at that time strongly in Socialist hands. According to Ross, it was Mitterand's turn from failed domestic Keynesian policies to Europe which crucially contributed to the success of the single market project. Even though European integration did not begin as a left affair, it had been relaunched in the 1980s by an interesting coalition of Kohl, Mitterand and Delors, where the two French socialist

\footnotetext{
25 I. Bache, S. George, S. Bulmer, Politics in the European Integration, $3^{\text {rd }}$ Edition (Oxford University Press.2011), at 159.

${ }^{26}$ A. Moravcsik, 'Negotiating the Single European Act', in R.O.Keohane, S.Hoffmann (eds), The New European Community: Decisionmaking and Institutional Change (Westwiev Press,1991), at 42.

27 Moravcsik, ibid,42; Pollack, note 17 supra, 273.
} 
politicians played the leading role. ${ }^{28}$ With the single market program and monetary integration, both deeply liberal economic initiatives, at the heart of the relaunch, this new intiative helped to convert Europe to post-Keynesian outlook. Hence, it was French Socialist's transformation from traditional post World War II Keynesian leftism to centre-leftism build around the new single market initiative which paradoxically made centre-leftism obligatory for other European Left parties. ${ }^{29}$ Since the SEA represented 'a massive advance' in the opening of the European markets ${ }^{30}$, the EC member states' autonomy in welfare issues was no longer secure. As the single market became almost a goal in itself, it was possible to argue that many social policy objectives represent non-tariff barriers to trade and as such violate the 'logic' of the single market. Consequently, during the next two decades, the EU was able vastly to expand the scope of the single market at the expense of the autonomy of member states to pursue autonomous welfare policies.

According to Scharpf, the European Court of Justice's (ECJ) role in this process is usually neglected by the literature explaining the success of these reforms. ${ }^{31}$ ECJ's early case law paved the way for a future reconfiguration of the original balance between the economic freedoms and social rights in the EU legal order. Scharpf argues that ECJ rulings in two early cases, Dassonvile $(1974)^{32}$ and Cassis (1979)33, crucially limited member states' discretion in formulating national policies and announced a new rule of mutual recognition ${ }^{34}$ which has $»$ changed the bargaining constellation and incentives

\footnotetext{
28 Ross, note 13 supra, 323.

29 ibid, 324.

30 M. Gilbert, European integration, A Concise History (Rowman \& Littlefield Publishers , Inc., 2012), at 139.

31 Scharpf, note 10 supra, 225.

32 Dassonvile, C-8/74, 11.07.1974.

33 Cassis, C-120/78, 20.2.1979.

34 The principle was only encapsulated in the Cassis ruling, but later explicitely formulated in the Commission's communication: Any product lawfully produced and marketed in one Member state must, in principle, be admitted to the market of any other Member State. See P.Craig,G. de Burca EU Law: Text, Cases and Materials, $5^{\text {th }}$ edition (Oxford University Press, 2011), at 649; K.
} 
that member states faces in the processes of European legislation. While in the past national law had remained in force as long as governments did not agree on a harmonization directive, the new default condition would be mutual recognition $« .{ }^{35}$ The paradox is that once the Court of Justice had established basic principles interpreting market freedoms in its own particular way, political bodies of the EU, with their veto position being undermined, had little choice but to follow the court's case law. Subsequently, the ECJ had extended the reach of its early rulings from free trade to free services delivery, free establishment, free capital movement and the free mobility of workers. This led, according to Scharpf, to a highly asymmetric institutional development: legal integration (integration through law), developed by an ever increasing case law of the ECJ, outpaced political integration impeded by heterogeneous interests of the member states. ${ }^{36}$ Due to the 'peculiar understanding' of economic freedoms by the ECJ, where the priority is assigned to the rights of capital holders over the socio-economic rights ${ }^{37}$ (Menendez, 2012, 70), the first asymmetry has also had a strong effect on the substantive direction of subsequent European legislation. ${ }^{38}$

Unlike in the national constitutional setting, where national courts have to balance the importance of economic and social dimensions, treating them as having an equal constitutional status, in ECJ jurisprudence the social clearly remained subordinate to the economic. ${ }^{39}$ Although with time and new amendments to the original Rome Treaty the line between the economic and

Alter, The European's Court Political Power. Selected Essays (Oxford University Press, 2009), at $142,143$.

${ }^{35}$ Scharpf, note 13 supra, 224.

${ }^{36}$ As Gilbert argues, while Cassis judgment provided an important stimuls for reform, we should not overestimate the extent to which the ruling opened the trade barriers within the EC. See Gilbert, note 29 supra, 131.

37 A.J. Menendez, 'A proportionate constitution? Economic Freedoms, substantive constitiutional choices and dérapages in European Union Law', in E. Chiti, A.J. Menendez, P.G. Teixera (eds), The European Rescue of the European Union? The existential crisis of the European political project, ARENA Report No. 3/12, RECON Report no. 19, at 70.

38 Scharpf, note 13 supra, 225.

${ }^{39}$ Menendez, note 34 supra, 106. 
the social has become blurred, it is important to emphasize that the social never achieved a constitutional parity with the economic. ECJ's judicial interpretation of market freedoms relies on various theoretical assumptions about the role of markets, governments and social policy in a market economy. The crucial flaw of the Court's doctrine lies in its orthodox subscription to a 'pre-realist' understanding of the market economy. One of the key insights of American legal realists, later developed by a progressive left wing school of thought, Critical legal studies, was that markets are not pre-political structures with a single natural form but a product of public/political regulation. ${ }^{40}$ One important implication of this claim is that there are many different forms that market economy can assume. When the ECJ decides issues which involve balancing of conflicting interests protected by market freedoms on one hand and social rights on the other, it usually relies on a concept of internal market which strongly resembles the concept of a market criticized by American legal realists. Here, the market or internal market is constructed as a non-political structure which exists in a certain 'natural' form where public regulation (in the form of social rights) only ex post facto changes the character of such a 'natural entity'. The Court's jurisprudence on internal market created a concept of market which became almost a goal in itself:

The European Court of Justice is neoformalist in its interpretation of the canonical freedoms of movement of goods and persons in a »single market« in part, as is widely recognized, in order to drape its legislative power in the cloak of legal necessity. ${ }^{41}$

\footnotetext{
${ }^{40}$ J.W. Singer, 'Review Essay: Legal Realism Now', (1988) 76 California Law Review 477.

41 D.Kennedy, 'Three Globalizations of Law and Legal Thought: 1850-2000', in D.M.Trubek, A.Santos (eds), The New Law and Economic Development: A Critical Appraisal ( Cambridge University Press, 2006) at 69.
} 
As a consequence, the 'economic constitution' was constructed as nonpolitical text juridified through supranational law, whereas social policy was conceptualized as 'a categorically distinct subject. It belonged to the domain of political legislation, and, as such, had to remain national'.42 Such depoliticization of EU constitutional law has had far reaching consequences for a future development of 'the social' in the EU constitutional legal order. The expulsion of the social from the constitutional level has paved the way for a particular juristic interpretation of the European constitution. According to Scharpf, it contributed to the fundamental asymmetry between market liberalization (negative integration) and social protection (positive integration) being now locked in the EU constitutional legal order. While the negative integration could be achieved quite easily, the positive integration was impeded by a 'joint decision trap' preventing governments to agree on common EU regulatory standards in crucial social policy areas. Hence, the reconfiguration of the original balance between the economic freedoms and social rights has been crucially shaped by the 'peculiar' judicial interpretation of core constitutional provisions (four freedoms) of the EC Treaty. ${ }^{43}$

For Delors, the single market programme was only the first step in a more ambitious programme of integration. He strongly believed that the economic liberalization programme would be followed by both monetary union and creation of 'social Europe'. ${ }^{4}$

While he was very successful in promoting common currency, his 'social Europe' idea was a gamble (Ross, 2011). ${ }^{45}$

\footnotetext{
42 Joerges, note 16 supra, 70.

43 Barnard criticizes such 'market access' approach and argues for adoption of 'discriminationbased' approach, modeled upon the US Supreme Court jurisprudence to the Commerce Clause. See C.Barnard, 'Restricting Restrictions: Lessons for the EU from the US?', (2009) 68 Cambridge Law Journal 577.

${ }^{44}$ Bache, George, Bulmer, note 24 supra, 166.

45 Ross, note 13 supra, 326
} 
In unique historical circumstances, marked by the 'acceleration of history' ( the collapse of Communism, the end of the Cold War and German reunification), and with a support of the key member states, The Treaty on European Union (the Maastricht Treaty) was signed in February 1992. Monetary union was by far the most important single policy initiative in the Maastricht Treaty. Premised on the neo-liberal foundations, EMU substantially constrained the ability of member states to pursue fiscal and economic policies substantially different from the prevailing ordoliberal ${ }^{46}$ orthodoxy of sound finance doctrine which found its place in the new Treaty provisions. EMU was embedded in a highly restrictive macroeconomic policy regime which was pre-Keynesian in its nature (Arestis, Sawyer, 2006; 6). ${ }^{47}$ Its key ingredients included the most independent central bank in the world (ECB) with the overarching emphasis on price stability and with an absolute priority of monetary policy which is taken as the main instrument of macroeconomic policy. Fiscal policy, on the other hand, was severely constrained by the rigid rules of the Stability and Growth Pact prohibiting member states from running excessive budget deficits and excessive general government debt. As explained by McNamara, the adoption of EMU followed a new neoliberal policy consensus which 'emphasizes the inherent stability and adaptability of the private sector and view traditional Keynesian efforts to manipulate the economy, particularly full employment strategies, as ineffective and possibly counterproductive'..$^{48}$

With ten out of twelve member states having conservative centre-right prime ministers, the broader neoliberal policy consensus about sound money

\footnotetext{
46 Ordoliberalism is a German version of neo-liberalism developed in the 1930s by the Freiburg School. See H.Rieter, M. Schmolz, 'The ideas of German Ordoliberalism 1938-45: pointing the way to a new economic order', (1993) 1 The European Journal of History of Economic Thought 87-114. 47 P.Arestis, M. Sawyer, 'Macroeconomic policy and the European Constitution', in P.Arestis, M.Sawyer (eds), Alternative Perspectives on Economic Policies in the European Union (Palgrave Macmillan, 2006) at 6.

48 K. McNamara, The Currency of Ideas: Monetary Politics in the European Union (Cornell University Press, 1998), at 145.
} 
doctrine and with a strong support of business, Delors was able to push the EMU forward. However, his 'social Europe' agenda was confronted with a strong neoliberal-nationalist coalition unwilling to follow Delors's proposal. Without the support of real political allies and 'swimming against the current of the neoliberal Zeitgeist', the Delors Commission counted on the neofunctionalist logic of market integration to necessitate Polanyi's countermovement leading to 'market correcting' Community institutions and policies. ${ }^{49}$ But, as it turned out, such neo-functionalist logic did not work as Delors wanted. As Streck has shown, a British led coalition between neoliberal advocates and other member states resisting harmonization easily defeated Delor's initiative. ${ }^{50}$

In other words, the original constitutional settlement was importantly redefined. The economic and the social, originally two parallel tracks, now started to collide. First, social protection policies at the national level had to be designed in the shadow of 'constitutionalized' economic law of the single market. Second, with the creation of the European and Monetary Union (EMU), member states not only lost its autonomous monetary policy but also agreed, through SGP, to important restrictions on their fiscal policies. Third, the EU accumulated substantial new jurisdictions in various social policy fields such as employment discrimination, equal pay, health and safety at work etc. All these developments led to the creation of 'semi -sovereign welfare states' in a multitiered system of social policy, where member states

\footnotetext{
${ }^{49}$ W. Streeck, 'From Market Making to State Building? Reflections on the Political Economy of European Social Policy', in in S.Liebfried, P.Pierson (eds), European Social Policy: Between Fragmentation and Integration (The Brookings Institution, 1995), at 402.

${ }^{50}$ W.Streeck, 'Neo-Voluntarism: A New European Social Policy Regime?', in G.Marks, F.W.Scharpf, P.Schmitter, W.Streeck (eds), Governance in the European Union, London (Sage Publications, 1996), at 75.
} 
have lost more autonomy in social protection policies than the EU has gained in transferred new social protection authority. ${ }^{51}$

Nevertheless, the new EU constitutional settlement after the SEA and Maastricht Treaty differs from the orthodox Anglo-Saxon neoliberalism. According to van Apeldoorn ${ }^{52}$, it represents a continental European-style neoliberalism which combines supranational marketization on the EU level with social elements on the national level, the latter being gradually hollowed out by the former. From a constitutional law perspective, it is important to emphasize that although the new embedded neoliberalism seriously challenges the constitutional balance between open market and social protection, it does not explicitly rule out progressive social policies. As we will see later, on this issue the Rubicon has been crossed with the EU response to the euro crisis.

\section{Divided EU Left and European Integration}

The EU thus entered the next stage of integration with significantly altered original constitutional settlement. If under the Rome Treaty the social was constitutionally protected from the economic, after the SEA and the Maastricht Treaty it had to confront the expansive logic of the internal market and the constraining logic of the EMU. Bolstered with the activist jurisprudence of the Court of Justice, the economic constitution gradually started to encroach upon the social, making the latter derivative of and

\footnotetext{
${ }^{51}$ S. Liebfried, P.Pierson, 'Semisovereign Welfare States: Social Policy in a Multitiered Europe', in S.Liebfried, P.Pierson (eds), European Social Policy: Between Fragmentation and Integration (The Brookings Institution, 1995), at 44.

52 B. van Apeldoorn, 'The Contradictions of "Emedded Neoliberalism" and Europe's Multi-level Legitimacy Crisis: The European Project and its Limits', in B.van Apeldoorn, J. Drahokoupil, L. Horn (eds), Contradictions and Limits of Neo-Liberal European Governance: From Lisbon to Lisbon (Palgrave Macmillan, 2009), at 24.
} 
subordinated to the former. The original balance between the economic and the social was changed so as to undermine the initial parity between the two. The Left was suddenly confronted with a new kind of constitutional order which clearly favoured the economic constitution of the internal market over social protection.

As the original constitutional compromise begun to unravel so did the consensus among the Left and Centre-Right about the aims of the internal market. Between mid-1980s and mid- 1990s there was a broad consensus among the Left and the Right concerning the importance of the single market. However, as the policy agenda shifted from creating the single market to the question of how regulated or liberalized the single market should be, the polarization along the Left-Right political axis has increased..$^{53}$ The period of 'permissive consensus' when European insulated elites could cut deals without a broader participation of European citizenry was then over. ${ }^{54}$ In these new circumstances, the volume of legislative acts adopted by the EU dramatically declined due to radically different positions between the European Left and Centre-Right on the substance of proposed legislation. ${ }^{55}$

For example, when the Centre-Right Commission led by Barroso proposed a new Services Directive (2006) $)^{56}$ aimed at introducing the country of origin principle for services, the attempt of liberalization of services came under a joint attack from the French and German governments and many left-wing MEPs, who opposed the Directive on the grounds that it would undermine the high social standards that apply to most services in many member states. Opposing the Services Directive, the Left organized one of the first and largest

\footnotetext{
${ }^{53}$ S. Hix, What's Wrong with the European Union \& How to Fix It (Polity Press, 2008), at 32.

${ }^{54}$ L.Hooghe, G.Marks, 'A Postfunctionalist Theory of European Integration: From Permissive Consensus to Constraining Dissensus', (2008) 39 British Journal of Political Science 5.

55 Hix, note 50 supra, 46.

56 Services Directive, 2006. DIRECTIVE 2006/123/EC OF THE EUROPEAN PARLIAMENT AND OF THE COUNCIL of 12 December 2006 on services in the internal market, OJ 2006), L376/26.
} 
demonstrations in the front of the European Parliament which helped to defeat the original 'neoliberal' text of the Directive aiming at full liberalization of services in the EU. After the ECJ issued a series of judgments in 200757 concerning the impact of EU law on national labour law, the question about the compatibility of social rights with the EU economic constitution became even more pressing. As the ECJ ruled in favour of economic rights, there was a widespread perception that the EU economic constitution is threatening social policy by favouring economic integration.

But if the EU constitution systematically biases policy making in the neo liberal direction, then the role of the Left in creating such order has to be critically examined as well. Any reflection on the nature of the European Union thus has to be also a critical reflection on the identity and ideology of the European Left. Namely, as I argued above, the European Left supported both the creation of a single market and of the EMU, which were crucial changes to the original Rome Treaty.

From this perspective, it is interesting to examine how the European Left responded to the described erosion of social rights under the EU economic constitution. In the late 1990s, when 13 out of 15 member states were ruled by social democrats, the European Left enjoyed a unique period of strong social democratic hegemony in the EU politics. ${ }^{58}$ As we will see, social democrats failed to use this unique historic period to lock in a social democratic perspective into the EU constitutional order. Although often described as a modest Treaty, the Treaty of Amsterdam nonetheless represented a unique

\footnotetext{
57 ECJ, Case C-438/05, International Transport Workers' Federation, Finnish Seamen's Union v. Viking Line ABP, OÜ VikingLine Eesti, ECR 2007, I-10779; ECJ, Case C-341/05, Laval un Partneri Ltd v. Svenska Byggnadsarbetareförbundet, ECR 2007, I-11767; ECJ, Case C-346/06, Rechtsanwalt Dr. Dirk Rüffert v. Land Niedersachsen, ECR 2008, I-01989.

58 As Streeck explains, the first attempt to create a comprehensive social policy at European level happened in the early 1970s and was largely driven by social.democratic governments to be in power in the key countries at that time. However, the Social Action Programme of 1972 was easily defeated by a British led coalition between neoliberals and nationalist resistance to harmonization. See Streeck, note 47 supra, 158.
} 
opportunity for the Left to constitutionalize their social democratic agenda and thus re-balance the dominant neoliberal thrust of the previous two Treaty changes.

However, at the meeting of socialist leaders in Malmö, shortly before the Amsterdam Council, it became clear that the diversity of views within the European Left was so big that it prevented a concerted Left approach in the negotiations leading to Amsterdam Treaty. ${ }^{59}$ While the newly elected French prime minister Jospin attacked the neoliberal and monetarist thrust of European integration and demanded a social democratization of the EMU, the British Prime minister Blair presented his own, a 'third way' version of European social democracy strongly opposed to any idea of binding regulation and intervention in employment policy at the European level. ${ }^{60} \mathrm{By}$ introducing and expanding the EU competences in employment, social policy, equal opportunities, environmental protection, consumer protection and human rights, the Treaty of Amsterdam (1997) was definitely 'an outlier' in comparison with other Treaties, focusing more exclusively on neo-liberal agenda of creation of a unified single market. But on the other hand, it felt short of constitutionalizing an alternative social democratic EU agenda. Although the new Employment Chapter and a modernized Social Chapter represented important change of the EU economic constitution, formally making a high level of employment an EU constitutional objective, Blair together with Kohl blocked any attempt to grant the EU any significant or regulatory powers in this area. ${ }^{61}$ Instead, the Treaty accepted Blair's version of 'voluntaristic' approach relying entirely on coordination and monitoring of national employment policies. The Left has thus has failed to use a rare

\footnotetext{
59 Pollack, note 17 supra, 283.

60 ibid, 284.

61 ibid, 285.
} 
instance of its political hegemony to more radically change the neoliberal bias of the EU constitution.

A similar story happened during the debates of the Convention on the Future of Europe, a precursor to future Lisbon Treaty. An important part of the Left again pressed for a constitutionalization of 'social Europe', based on truly federalized social policy and extension of qualified majority voting (QMV) in the Council, but it was again blocked by a coalition of the right parties which were joined by the Nordic Social Democrats and Blair's Labour Party fearing that any extension of EU competencies might undermine their national welfare models. ${ }^{62}$ As Ross argues, this can be explained by an established Euro sceptical tradition of many deeply social democratic lefts in Europe (Sweden, Denmark, Austria) strongly favouring protection of their own domestic welfare models. ${ }^{63}$

What these examples clearly show is that while the European Left was definitely constrained by the asymmetric logic of the institutional order, which by the way the Left also helped to construct, there were other issues which equally if not more importantly than the legal structure contributed to the absence of a well-defined, concerted Left approach to European integration:

Irrespective of the limits imposed by EU institutions on the left's influence, to have influence European lefts need to agree on what they want to do together. Here is where the largest problems for center-lefts arise. ${ }^{64}$

It is only the diversity of views within the European Left that inhibits a creation of common EU agenda. The fact that European social democrats did

\footnotetext{
62 D. McCann, D, The Political Economy of the European Union: An Institutionalist Perspective (Polity Press, 2010), at 137.

63 Ross, note 13 supra, 334.

64 ibid, 332-333.
} 
not have a common programme for economic regulation at the EU level is also explained by the 'fundamental failure of imagination'. ${ }^{65}$ For the most part of the brief history of European integration, the European Left remained imprisoned within the nation state logic of progressive social policy. The European Left never really developed a post-national, EU approach to social policy. It usually oscillated between the defensive approach of protecting domestic welfare states and by and large unsuccessful approach to extend the national model to the EU level. Although these two approaches are quite different, they share one important thing: both use a nation state model of social policy as their preferred template for EU policy. This predicament of the European Left is best explained by Amato, a former Italian prime minister and an academic:

In the long history of social rights the workers and their organisations have been the promoters of their own progress and the more they have succeeded the more they have gained instruments for not just being promoters, but also co-decision makers of the steps forward. They are historically used to playing this role at the national level. For the future they have to get accustomed to play it more and more at the European one. ${ }^{66}$

It is surprising how few ideas about alternative 'possible Europes' are being put forward. It seems that one of the major problems of the European Left is the lack of institutional imagination and programmatic thinking which could offer new ideas about alternative, possible Europes. The European Left must start to think how to transcend the 'false necessity' of European neoliberal constitutional order. In order to do that, it must also transcend the nation state approach to social Europe, which unnecessarily limits the range of options

\footnotetext{
65 C.S. Allen, 'Social Democracy, Globalization and Governance: Why is there no European Left Program in the EU?', Paper presented at the Minda de Gunzburg Center for European Studies, Harvard University, April 3, 2000.

66 G.Amato, 'Making Social Europe European', (2008) 4 Social Europe 31.
} 
available to the European Left to basically two main possibilities: either to a defensive strategy of the re-nationalization of social policy, or to a traditional social-democratic attempt to reconstruct a Keynesian welfare state on the EU level. As Ferrera argues, there is a third option, promising to reconcile the social model centred on the welfare state with the political model centred on the EU model of multi-level governance. The novelty of this approach is in its attempt to strengthen the national welfare state by its more effective and explicit 'nesting' within the overall institutional framework of the EU. ${ }^{67}$

As the EU faces its most severe political and economic crisis since its formation, it becomes even clearer that the European left needs to rethink its approach to economic and social regulation at the EU level. With several Treaty amendments and other 'turbo-speed' legislative activities aimed to solve the euro-zone debt crisis, the Right Centre coalition under a strong hegemony of the German Chancellor Merkel has fundamentally transformed the economic constitution .68 With adoption of the Fiscal Treaty, ESM, European Semester, Euro Plus Pact, Six Pack, this time, the EU risks undermining the 'substantive balance' between the market integration and social policy that sustains the legitimacy of the integration project. ${ }^{69}$

While previous Treaty amendments tilted the EU economic constitution strongly into the neo-liberal direction, they nonetheless included legal provisions protecting redistributive autonomy of member states at the national level. This time, the 'Union has been transformed into a political

\footnotetext{
${ }^{67}$ M. Ferrera, 'The JCMS Annual Lecture: National Welfare States and European Integration: In Search of a "Virtuous Nesting', (2009) 47 Journal of Common Market Studies 220.

68 C. Joerges, 'The European Economic Constitution and Its Transformation Through the Financial Crisis', forthcoming in D.Patterson, A,Söderstn (eds), A Companion to European Union Law and International Law (Wiley-Blackwell, 2013).

${ }^{69}$ M. Dawson, F. de Witte, 'Constitutional Balance in the EU After the Euro-Crisis', (2013) Modern Law Review, forthcoming.
} 
system redistributing significant wealth within its territory'. ${ }^{70}$ For the first time in the EU history we see an emergence of a new economic constitution which explicitly entrenches one economic paradigm at the expense of other alternatives, with simultaneously dismantling the remaining protections of social policy autonomy of member states. This approach is not only constitutionally problematic, but also economically questionable. ${ }^{71}$ It threatens the very existence of the EU as we have known it. As Schmidt argues, at the moment only a renewed social democratic agenda can help to solve this problem. ${ }^{72}$

\section{Toward European Austerity Union: EU Constitution after the Euro crisis}

Confronted with the deepest economic and political crisis of the EU since its inception, European political leaders responded with a series of legislative measures aimed primarily to solve the euro-zone debt crisis. In the last two years, they adopted European Semester (2010), European Financial Stability Facility (2010), Euro-Plus Pact (2011), Six-Pack (2011), European Stability Mechanism (2012) and Treaty on Stability, Co-ordination and Governance in the Economic and Monetary Union (a.k.a. the Fiscal Treaty, 2012). The economic theory behind all these rules is that a profligacy of 'irresponsible' states and their public sectors is the main reason for the current euro crisis. Hence, the best approach to solve the crisis is to impose strict new rules which aim to discipline such 'irresponsible' countries. In other words, the imposition

\footnotetext{
70 D. Chalmers,' The European Redistributive State and a European Law of Struggle', (2012) 18 European Law Journal 667.

${ }^{71}$ L.King, M. Kitson, S. Konzelmann, F. Wilkinson, 'Making the same mistake again- or is this time different?', (2012) 36 Cambridge Journal of Economics 6.

72 V. Schmidt, 'The Unfinished Architecture of Europe's Economic Union', (2010) 23 Governance 555-559.
} 
of strict austerity through balanced budgets and stricter fiscal rules became a new dominant economic ideology of the EU current leadership lead by Merkel and Sarkozy.

Despite the fact that the austerity approach rests on a wrong diagnosis of the euro crisis ${ }^{73}$, that it does not work economically and that it has strong negative economic and social consequences for indebted countries, it still remains virtually unchallenged 'official' economic doctrine of the current EU leadership. However, the elections in France in May 2012 brought to power a new Socialist president Hollande, one of the most vocal critics of the austerity in Europe. With the euro zone debt crisis further deteriorating, other important institutions such as IMF and the US Treasury also voiced a strong criticism of the austerity orthodoxy and urged for a new pro-growth approach. As a consequence, during the June 2012 Euro Area Summit the debate shifted from austerity to growth and several EU leaders urged for a new growth pact to complement the Fiscal Treaty. However, while making certain important concession to the pro-growth advocates (Hollande and Monti $)^{74}$, the conclusions of the Summit felt short of producing a more ambitious alternative to Merkel's austerity policy.

The politics of strict austerity has profound constitutional implications for the EU legal order. It represents nothing less than a fundamental transformation of the economic constitution. ${ }^{75}$ For the first time the substantive balance of the EU ensuring 'the relative neutrality'76 of the Union's policies has been explicitly disregarded.

\footnotetext{
${ }^{73}$ A. Moravcsik, 'Europe After the Crisis: How to Sustain a Common Currency', (2012) 91 Foreign Affairs 57.

74 The Summit conclusions contain also an annex entitled «A Compact for Growth and Jobs«, European Council 28/29 June, 2012 Conclusions.

75 Joerges, note 63 supra.

76 Dawson, de Witte, note 64 supra.
} 
The Fiscal Treaty ${ }^{77}$, for example, basically entrenches a certain economic theory at the level of constitutional law requiring the signatories of the Treaty to change their constitutions, preferably, with new provisions of binding force and permanent character..$^{78}$ In other words, the signatories of the compact are asked to introduce into their constitutions provisions which can't be changed through regular amendment procedures. As a consequence, the austerity policy of Angela Merkel thus achieves binding and eternal legal validity. While it elevates the austerity paradigm of the German Chancellor Angela Merkel to the status of 'unbreakable law', it basically outlaws Keynesianism and its counter-cyclical economic policies. No surprise then that in the editorial, one of the leading constitutional journals in Europe concludes that the Fiscal compact 'strikes at the heart of the institutions of parliamentary democracy by dislocating as a matter of constitutional principle the budgetary autonomy of the member states'. ${ }^{79}$ In addition, the European Court of Justice was given new powers to determine whether the member states comply with their duty to introduce balanced budget rules into their constitutional legal order. Such new power represents unprecedented constitutional intrusion, since the European Court of Justice never had the power to interpret national constitutions of the member states.

Other measures such as The Euro- Plus Pact and The European Growth Pact on the other hand explicitly suggest coordination and harmonization of such

\footnotetext{
77 The Fiscal Treaty requires ratifying member states to enact laws, preferably of a constitutional nature, requiring national budgets to be in balance or in surplus. The treaty defines a balanced budget as one which has a general budget deficit less than 3\% of GDP and a structural deficit of less than either $0.5 \%$ or $1 \%$, depending on a countries debt-to-GDP ratio. The aim of this "golden rule" of balanced budgets is to ensure budgetary discipline among the EU governments. Another element of the Fiscal compact is so called "debt brake" modeled upon the German constitutional provision requiring the federal government to reduce its structural deficit to $0.35 \%$ of GDP by 2016. The treaty also places compliance with its budgetary and other requirements under the jurisdiction of the European Court of Justice.

${ }^{78}$ Article 3, paragraph 2 of the Fiscal Treaty.

79 Editorial, 'The Fiscal Compact and the European Constitutions:"Europe Speaking German"', (2012) 8 European Constitutional Law Review 5.
} 
contentious welfare issues as pension schemes, social benefits and employment policies. Access to bail out funds, provided by EFSM and EFSF, requires prior ratification of the Fiscal Treaty and signing a Memorandum of Understanding which requires very specific and detailed reforms. Financial aid to Greece and Portugal is conditional on VAT increases, pension cuts, and the liberalization of public services. ${ }^{80}$ The latest example of this new forms of austerity constitutionalism are 'Contracts for Competitiveness and Growth', proposed by the EU Commission. The main idea behind the Contracts is that the governments in trouble would get the EU financial support with temporary conditional transfers based upon previous agreement with the EU on the content of a policy agenda. ${ }^{81}$

Another important feature of these new instruments is that they side-line national parliaments and empower technocrats and judges to decide whether the member states fiscal policies are in compliance with the EU rules. Once a country is found in breach of these fiscal obligations, the Commission, the Council, and the ECJ have extensive powers of control and sanction over a member state fiscal policy. As argued by a prominent economist, 'the profoundly undemocratic nature this approach is clear- the unelected European Commission can "request" that the elected national parliament and government to change its budget'. 82

The new Austerity Union thus undermines the most fundamental principles of 'substantive balance' in the EU constitutional order. These principles, enshrined in the original Rome Treaty, provided a workable balance between Union's economic goals and national redistributive social policies. As I argue

\footnotetext{
80 F.W. Scharpf,' Montary Union, Fiscal Crisis and the Preemption of Democracy', MPlfG Discussion Paper 11/2011, 28.

${ }^{81} \mathrm{~J}$. Pisani-Ferry, 'Bribery is no way to reform Europe's economy', Financial Times, February 6, 2013, p.7.

82 M.Sawyer, 'The EU Fiscal Compact', December 12, 2011. At http://triplecrisis.com/the-eufiscal-compact/print
} 
in Section 3, this balance has already been redefined in the 1980s with the single market project and monetary union. Nonetheless, the economic constitution of the Union has never so directly affected the member states' autonomy in its redistributive policies as it does with the newly adopted constitutional components of the emerging Austerity Union. ${ }^{83}$

In their critical assessment of this new model for the EU, Leonard and Zielonka argue that Europe needs a different model of integration to survive:

To survive the crisis, European leaders should embrace pluralism, participation and solidarity rather than the technocratic centralism of rules and sanctions. ${ }^{84}$

As Schmidt argues, it is quite clear that impetus for such a new approach will not come from the austerity camp. ${ }^{85}$ German Chancellor Merkel, Barroso and Van Rompuy, supported by a group of Northern countries, remain firmly devoted to their austerity approach. European left, on the other side, is politically weak and curiously absent from political debate on the euro zone crisis. Brown, Halpin and Texeira describe this situation as the 'European paradox', where paradox refers to the failure of the European left to capitalize on the strong association between conservative reverence for the unfettered market and the current economic crisis. ${ }^{86}$ As I tried to argue in this article, such a failure cannot be attributed solely to the constitutional structure of the Union. The Left needs to offer a new approach to the EU economic and social policy making which transcends the limits of the nation state model.

\footnotetext{
83 Joerges, note 63 supra; Dawson, de Witte, note 64 supra.

84 M.Leonard, J.Zielonka, 'A Europe of Incentives: How to Regain the Trust of Citizens and Markets', European Council on Foreign Relations, June 2012, 13.

85 V.Schmidt, 'Can the Bicycle Turn into a Jet Plane by 2020? Two Patways for Europe', The EuroFuture Project, Paper Series, September 2012.

86 Brown, Halpin, Texeira, note 2 supra, 3.
} 
Current EU crisis is thus both challenge and opportunity for the European Left. By reforming itself, the Left could also offer a new vision for Europe. How well is the European Left prepared for such an occasion? Despite the fact that all key positions in the EU are momentarily in the Centre-Right hands, there are some promising news. If there were elections tomorrow, the Centre-Left would for the first time win a majority in the European Parliament (Hix, Marsh, Predict09, 2012). ${ }^{87}$ The Party of European Socialists (PES), a coalition of the socialist, social-democratic and labour parties of the EU, came out with a new Socialist Manifesto 'For a European Socialist Alternative' (PES, 2012)..$^{88}$ By and large a response to the Merkel's politics of austerity, Manifesto offers some proposals which signal a departure from the traditional Left EU strategy. Several proposals from the Manifesto advocate a constitutional re-orientation of the EU, but, curiously, not towards a federalized welfare state. Although the Manifesto falls short of proposing needed radical institutional innovation, it contains certain elements that point in that direction. For example, they propose 'an economic policy for the Union which places the economic and social objectives laid down in the Treaty (growth, full employment, social inclusion), at the heart of policy-making with just as much vigour and organisational firepower as that accorded to the objective of budgetary discipline'. ${ }^{89}$ Interestingly, the means to achieve this end (budget reform, European Project Bonds, promotion of social, infrastructure and sustainable development investment), offer a new approach to 'social Europe' where the proposed European economic and social policy seeks rather to strengthen than displace various national models of welfares states and varieties of capitalism. Nevertheless, in order to make the Manifesto a new platform for a common EU strategy, the Left need to

${ }^{87}$ S.Hix, M.Marsh, New Prediction of the outcome of the European Parliament elections, based on their Predict09.eu (2012)

88 PES, For a European Socialist Alternative (2012), available at http://europeansocialistalternative.blogspot.com/ 89 Ibid. 
avoid some of the past mistakes. Only a concerted, European response of the European Lefts offers a hope that they could reverse the course of European history and make the EU again, as it was in its early days, both the protector and promoter of European nation states. ${ }^{90}$

\section{Conclusion: Constitutional limits to Progressive Politics?}

Constitutions in politically liberal nation states usually don't discriminate among different political ideologies. ${ }^{91}$ While constitutions impose certain limits on legislative politics, primarily through the protection of constitutional rights, it can hardly be argued that, on balance, they privilege one or another political ideology. The EU 'economic constitution' is, in this respect, different. It systematically biases EU policy making in a neo-liberal direction. Historically speaking, this was not the intent of the EU founding fathers. The original constitutional settlement of embedded liberalism was significantly redefined in the next major revisions of the Rome Treaty. The neo-liberal foundations of the single market and the EMU have imposed real and significant institutional constraints for progressive policy making. However, the role of the European Left was crucial in this alteration of the EU constitutional order. Despite the strong neoliberal consensus among the key political actors of that time, such a change would have not be possible without the Left' retreat towards 'centre-leftism', particularly in France. Furthermore, while constrains of the EU economic constitution are significant,

\footnotetext{
90 Milward, note 16 supra.

91 For persuasive argument that many constitutions in Latin America do favour certain political ideologies, such as social democracy or neo-liberalism, see D.Brinks, W.Forbath, 'The role of courts and constitutions in the new politics of welfare in Latin America', unpublished paper, 2013.
} 
we should avoid the 'naturalization' of the EU, 'depicting it as an automatic upshot of a wholly impersonal logic'.92 As Rosemond argues, such view downplays the contingency of such logic .93 The European Left, while in power, failed to leave its distinct imprint on the EU economic constitution. Despite certain quite important achievements (Employment Chapter, Social Chapter, equal protection, environment, health and safety), the Left failed to promote a coherent EU approach to 'social Europe'. The Left policy agenda remained firmly embedded in the logic of the nation state. The euro crisis pushed these developments even further and, for the first time in the EU history, explicitly challenged the constitutional balance of the EU legal order. The new Austerity Union, a project in the making, profoundly altered this constitutional balance. The new politics of austerity is both politically and economically flawed. It threatens the very foundations of European integration. The euro crisis thus represents both a challenge and opportunity for the Left to offer an alternative response to the biggest EU crisis since its inception. But in order to succeed, the European Left must first reform itself. The PES Manifesto is a promising sign in that direction.

92 C.Hay, D. Wincott, The Political Economy of European Welfare Capitalism (Palgrave Macmillan, 2012), at 132.

93 B. Rosemond, 'Imagining the European Economy: Competitiveness and the Social Construction of "Europe" as an Economic Space', (2002) 7 New Political Economy 157-177. 


\section{Recent LEQS papers}

Somek, Alexander. 'Europe: From emancipation to empowerment' LEQS Paper No. 60, April 2013

Kleine, Mareike. 'Trading Control: National Chiefdoms within International Organizations' LEQS Paper No. 59, March 2013

Aranki, Ted \& Macchiarelli, Corrado. 'Employment Duration and Shifts into Retirement in the EU' LEQS Paper No. 58, February 2013

De Grauwe, Paul. 'Design Failures in the Eurozone: Can they be fixed?' LEQS Paper No. 57, February 2013

Teixeira, Pedro. 'The Tortuous Ways of the Market: Looking at the European Integration of Higher Education from an Economic Perspective' LEQS Paper No. 56, January 2013

Costa-i-Font, Joan. ' Fiscal Federalism and European Health System Decentralization: A Perspective' LEQS Paper No. 55, December 2012

Schelkle, Waltraud. 'Collapsing Worlds and Varieties of welfare capitalism: In search of a new political economy of welfare' LEQS Paper No. 54, November 2012

Crescenzi, Riccardo, Pietrobelli, Carlo \& Rabellotti, Roberta. 'Innovation Drivers, Value Chains and the Geography of Multinational Firms in European Regions' LEQS Paper No. 53, October 2012

Featherstone, Kevin. 'Le choc de la nouvelle? Maastricht, déjà vu and EMU reform' LEQS Paper No. 52, September 2012

Hassel, Anke \& Lütz, Susanne. 'Balancing Competition and Cooperation: The State's New Power in Crisis Management’ LEQS Paper No. 51, July 2012

Garben, Sacha. 'The Future of Higher Education in Europe: The Case for a Stronger Base in EU Law' LEQS Paper No. 50, July 2012

Everson, Michelle. 'A Technology of Expertise: EU Financial Services Agencies' LEQS Paper No. 49, June 2012

Cherrier, Nickolas. 'EU Diplomacy at 27: United in Diversity?' LEQS Paper No. 48, May 2012

White, Jonathan. 'Parallel Lives: Social Comparison Across National Boundaries' LEQS Paper No. 47, January 2012

Meyer, Niclas. 'Political Contestation in the Shadow of Hierarchy' LEQS Paper No. 46, January 2012

Hyman, Richard. 'Trade Unions, Lisbon and Europe 2020: From Dream to Nightmare' LEQS Paper No. 45, December 2011

Wagner, Peter. 'The democratic crisis of capitalism: Reflections on political and economic modernity in Europe' LEQS Paper No. 44, December 2011

Chalmers, Damian \& Chaves, Mariana. 'The Reference Points of EU Judicial Politics' LEQS Paper No. 43, September 2011 


\section{LEQS}

European Institute London School of Economics Houghton Street WC2A 2AE London

Email: euroinst.LEQS@lse.ac.uk

http://www2.lse.ac.uk/europeanInstitute/LEQS/Home.aspx

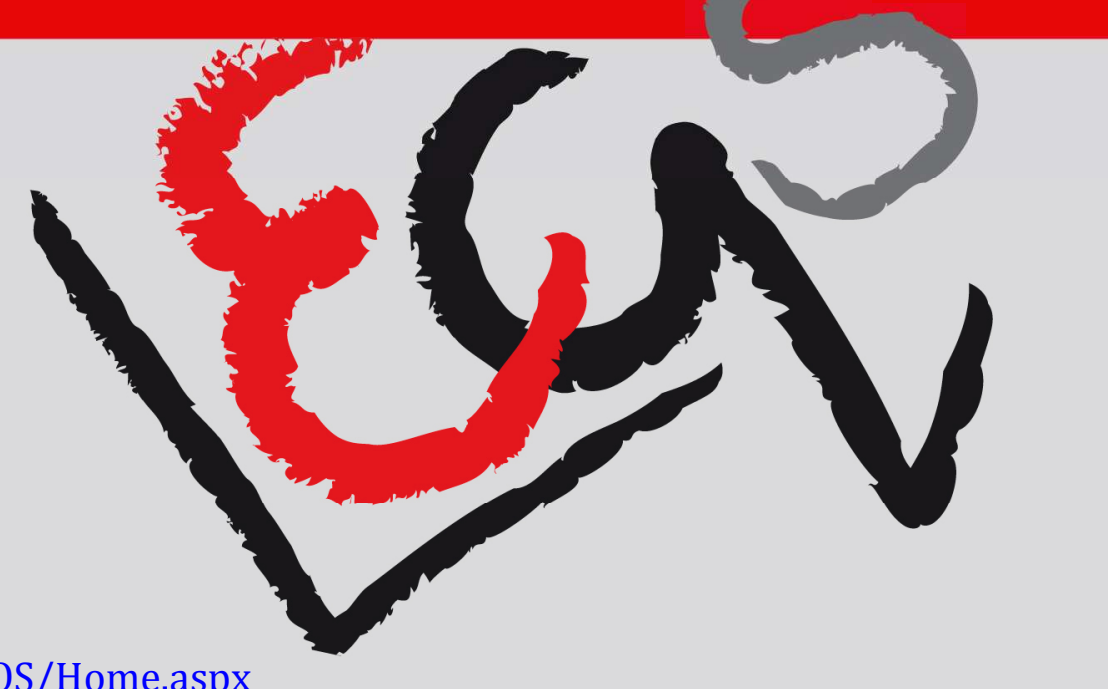

